\author{
Jerzy Bieluk \\ University in Bialystok, Poland \\ ORCID: 0000-0002-9949-472X \\ bieluk@uwb.edu.pl
}

\title{
River as a Legal Person
}

\author{
Rzeka jako osoba prawna
}

\begin{abstract}
SUMMARY
The concepts of recognizing elements of nature as having legal personality have been appearing for many years as proposals for a new approach to ecology. Recent years have brought specific solutions in this regard. Attempts to recognize rivers (but not only rivers) as separate legal entities can be found in various places around the world. This is not a common trend, only a few such cases can be identified in the applicable legislation. The article is devoted to the analysis of the best-known examples of this type of activity. In 2017, the legal system of New Zealand recognized the Whanganui River as a legal person. Talks are ongoing about further solutions of this kind. Apart from environmental protection reasons, the basic motives for this type of solution are cultural considerations - connected with Maori beliefs and values. In the legal systems of India and Colombia, the courts have attempted to recognize the rivers (Ganges and Yamuna in India, the Atrata River, and the entire Amazon ecosystem) as legal persons. The motives for this type of activity were primarily ecological - protecting priceless parts of nature from destruction.
\end{abstract}

Keywords: environmental protection; legal personality; river as a legal person; ecology

\section{INTRODUCTION}

The concepts of recognizing elements of nature as having legal personality have been appearing for many years as proposals for a new approach to ecology. Recent years have brought specific solutions in this regard. Attempts to recognize rivers (but not only rivers) as separate legal entities can be found in various places around the world. This is not a common trend, only a few such cases can be identified in the applicable legislation. However, this is a quite newsworthy matter - the slogan reading "A river becomes a legal entity" arouses even the interest of non-lawyers. At the same time, it is a very interesting legal structure, but it also requires looking 
from other - ecological, cultural - points of view. The article describes the concepts of recognizing elements of nature as independent legal persons and presents the implementation of these concepts in solutions already operating worldwide. The most important examples of such solutions are presented. The situation in this area is dynamic, so one should expect an increase in the popularity of the subjective approach to nature, especially since the issue of environmental protection is becoming more and more important and the ineffectiveness of the mechanisms used so far is increasingly visible. The article is only an introduction to the extensive issue on which several studies have already been published ${ }^{1}$. New Zealand, India, and Colombia were selected for the presentation, while attempts to introduce the concept of elements of nature as legal persons can also be seen in other countries ${ }^{2}$.

\section{THE CONCEPT OF ELEMENTS OF NATURE AS HAVING THEIR OWN RIGHTS}

The idea that the elements of nature should have a legal personality is not new. It was propagated by Ch.D. Stone in the article published in 1972 entitled Should Trees Have Standing? - Toward Legal Rights for Natural Object ${ }^{3}$. This publication started a discussion on the possibility of granting legal personality to such elements of nature as mountains, rivers, etc. The author postulated giving legal personality to parts of nature to provide them with greater protection, but above all, he called for redefining human relations with nature. These postulates acquire relevance in the context of the increasingly exposed ecological issues.

1 See, among others, H.M. Babcock, A Brook with Legal Rights: The Rights of Nature in Court, "Ecology Law Quarterly" 2016, Vol. 43(1); E.L. O’Donnell, M. Maloney, C. Parker, New developments in the legal status of rivers, 11 August 2017, https://law.unimelb.edu.au/_data/assets/pdf_file/0007/2516479/Legal-rights-for-rivers-Workshop-Report.pdf [access: 5.11.2019]. See also a comprehensive study on New Zealand: R. Joseph, M. Rakena, M.T. Kuini Jones, R. Sterling, C. Rakena, The Treaty, Tikanga Māori, Ecosystem-Based Management, Mainstream Law and Power Sharing for Environmental Integrity in Aotearoa New Zealand - Possible Ways Forward, Waikato 2019, https://sustainableseaschallenge.co.nz/sites/default/files/2019-02/MAIN\%20TuhonohonoSSeas\%20Final\%20Report\%20Nov\%202019.pdf [access: 5.11.2019].

2 See Australia (Yarra River): E.L. O’Donnell, J. Talbot-Jones, Creating legal rights for rivers: Lessons from Australia, New Zealand, and India, "Ecology and Society" 2018, Vol. 23(1), DOI: https://doi.org/10.5751/ES-09854-230107; Ecuador (Vilcabamba River): M.V. Berros, Defending Rivers: Vicamaba in the South of Ecuador, "Perspectives Issue" 2017, No. 6; USA (Colorado River): C. Clark, N. Emmanouil, J. Page, A. Pelizzon, Can You Hear the Rivers Sing? Legal Personhood, Ontology, and the Nitty, Gritty of Governance, "Ecology Law Quarterly" 2018, Vol. 45.

3 Ch.D. Stone, Should Trees Have Standing? - Towards Legal Rights for Natural Objects, "Southern California Law Review" 1972, Vol. 45. The article was developed into a book. See the $3^{\text {rd }}$ edition of 2010, Should Trees Have Standing? Law, Morality and the Environment (Oxford), further references refer to the 2010 release. 
The legal person is certainly an artificial construction, taking its pedigree in legal doctrinal considerations ${ }^{4}$. Commercial law companies, cooperatives, foundations do not exist in reality - they have their own assets (or not) and authorities, but it is difficult to consider them as bearing the attribute of real existence. In the case of a limited liability company, its legal personality is based on the fulfillment of several abstract conditions - a person (only one is enough) collects the amount of PLN 5,000, signs the articles of association (in the case of a single-member company - the founding act), selects the seat, appoints the management board and submits an appropriate application to the registry court ${ }^{5}$. In this way, a new legal entity is created. After a few unsuccessful investments, the initial capital may cease, the management board may resign and the legal entity may only become an entry in the National Court Register with no property nor representation. At least, in this case, we are dealing with a real designatum - we can see the river, determine its interests, the scope of its protection. The legislator decides which entity has legal personality and in the case of legal persons he also decides about the scope of their rights and obligations. It is also the legislator who can decide on the creation of new legal persons and determine their manner of representation, rules of functioning on the market, etc.

From the typical legal point of view, understandable argumentation, regarding the extension of the concept of a legal person to the elements of the environment, deserves attention. Nature needs protection. To receive it, nature should obtain legal personality and its own independent rights. In this way, it could sue the offenders and receive appropriate compensation ${ }^{6}$. However, here comes re-evaluation - for a moment it is not the man, but nature, that becomes the centre of attention ${ }^{7}$. The court is to assess damage to the environment without recourse to man. Nowadays, when actions for the sake of the environment become more and more significant, one may ask whether damage to a human being - even indirectly - should be

4 More broadly, see J. Frąckowiak, Osoby prawne, [in:] System Prawa Prywatnego, t. 1: Prawo cywilne-część ogólna, red. M. Safjan, Warszawa 2007, pp. 1003-1108. See also Ch.D. Stone, Should Trees Have Standing? Law..., pp. 1-2: „Nor I sit only matter in human form that has come to be recognized as the possessor of rights. The World of the lawyer is peopled with inanimate right holders: trusts, corporations, joint ventures, municipalities, Subchapter R partnerships, and nation-states, to mention just w few".

5 This is the case in Polish law, and in other legal systems the creation of a legal person can be further simplified.

6 As defined by Ch.D. Stone (Should Trees Have Standing? Law..., pp. 6-7), even if the injured entity (natural or legal person) wins a case in court with regard to the pollution of a river, "no money goes to the benefit of the stream itself to repair its damages".

7 See considerations on changing the relationship between nature and man in the context of property rights: A. De Vries-Stotijn, I. Van Ham, K. Bastmeijer, Protection through property: from private to river-held rights, "Water International" 2019, Vol. 44(6-7), DOI: https://doi.org/10.1080/ 02508060.2019.1641882, pp. 4-5. 
a premise for liability for damage to the environment, or whether we can accept the subjectivity of nature itself in this respect.

A legal person is a non-human entity with the right to the protection of personal rights, the right to compensation for losses suffered, etc. The legal person is represented by natural persons - speaking on its behalf, representing it, who do not act on their own account. However, the scope of rights of a legal person may be shaped differently by legislation. It is obvious that a river, even if endowed with legal personality by the legislator, will not have such rights as a human. As Ch.D. Stone stated:

[...] to say that the environment should have rights is not to say that it should have every right we can imagine or even the same body of rights as human beings have. Nor is it to say that everything in the environment should have the same rights as every other thing in the environment ${ }^{8}$.

The legal person is an artificial construction by all means - typically legal and utilitarian and serving specific purposes. The use of such an institution for universally accepted purposes can hardly be considered improper. Since any social relationship that has legal interests that justify it, can obtain legal personality, why not accept that it is possible to recognize that parts of nature, such as rivers, represented by people, have their own interests and their own rights.

\section{NEW ZEALAND: THE WHANGANUI RIVER}

The Whanganui River (Te Awa Tupua in the Maori language) is located in New Zealand. It flows from the centre of the North Island to its west bank - to the Tasman Sea, through the Maori area. In 1840 the government of New Zealand signed the Treaty of Waitangi with representatives of the Whanganui tribe, guaranteeing the Maori full control over the river and all its resources. However, this guarantee was included only in the Maori version of the Treaty. While the English version gave the government of New Zealand the full rights to all resources ${ }^{9}$. The agreement was not respected, only the English version was referred to or it was in general ignored ${ }^{10}$. A number of activities were carried out that violated the substance of the

8 Ch.D. Stone, Should Trees Have Standing? Law..., p. 4.

9 See www.treaty2u.govt.nz [access: 5.11.2019]. There is the whole history of the Treaty.

${ }^{10}$ R. Colwell, S. Carr-Wilson, C. Sandborn, Legal Personality of Natural Features: Recent International Developments and Applicability in Canada, 2017, www.elc.uvic.ca/wordpress/wp-content/ uploads/2018/05/2017-02-03-LegalPersonalityNatural-Features_web-version.pdf [access: 5.11.2019], pp. 6-17. 
river, such as dredging the riverbed to improve navigation, gravel extraction, and drainage of water for electricity ${ }^{11}$.

From 1870 until 2017, the Whanganui tribe constantly fought for the right to their land - for the right to protect the Whanganui River and for compensation for the damage suffered ${ }^{12}$. In 2011 specific negotiations began between the Whanganui tribe and the government of New Zealand. They continued until 2017 and one of the basic conditions set by the Maoris was to grant legal personality to the river. In 2014 an agreement was reached as to the compensation related to the violations of the agreement and, above all, it was recognized that the river has legal personality. The agreement was implemented in 2017 - and since March 11, 2017, the Whanganui River (Te Awa Tupua) has had legal personality. It was stated that:

12 (1) Te Awa Tupua is an indivisible and living whole, comprising the Whanganui River from the mountains to the sea, incorporating all its physical and metaphysical elements. [...]

14 (1) Te Awa Tupua is a legal person and has all the rights, powers, duties, and liabilities of a legal person ${ }^{13}$.

The Whanganui River has a special place in Maori culture and beliefs. It is considered by them as an ancestor - the tribe believes that people are inseparable from the river. As stated in an official document entitled "Record of understanding in relation to Whanganui River settlement":

1.4. The Whanganui River is central to the existence of Whanganui Iwi and their health and wellbeing. The River has provided both physical and spiritual sustenance to the Iwi from time immemorial. From the earliest times the Whanganui River has acted as an artery for Māori inhabiting its forests and fertile river terraces and travelling to and from the central North Island. [...]

1.18. The vision of Whanganui Iwi for the settlement of the Whanganui River claim is founded on two fundamental principles:

1.18.1. An integrated, indivisible view of Te Awa Tupua in both biophysical and metaphysical terms from the mountains to the sea.

1.18.2. The health and wellbeing of the Whanganui River is intrinsically interconnected with the health and wellbeing of the people ${ }^{14}$.

${ }^{11}$ More broadly, see C.J. Iorns Magallanes, Nature as an Ancestor: Two Examples of Legal Personality for Nature in New Zealand, „VertigO - la revue electronique en sciences de l'environnement” 2015, serie 22, DOI: https://doi.org/10.4000/vertigo.16199, pp. 4-5.

12 See Summary of the historical background to the Whanganui River claims of Whanganui Iwi, www.govt.nz/treaty-settlement-documents/whanganui-iwi/whanganui-iwi-whanganui-river-deed-ofsettlement-summary-5-aug-2014/background [access: 5.11.2019].

13 Te Awa Tupua (Whanganui River Claims Settlement) Act 2017, www.legislation.govt.nz/act/ public/2017/0007/latest/whole.html\#DLM6831461 [access: 5.11.2019].

${ }^{14}$ The content of the Terms of negotiation is available on the website: www.ngatangatatiaki. co.nz/assets/Uploads/Important-Documents/DocumentLibrary_WhanganuiRiverROU.pdf [access: 5.11.2019]. 
The grounds for considering the river as a legal person are in the beliefs and visions of the Maori world ${ }^{15}$. It should be remembered when thinking about the solutions present in New Zealand, that the Western worldview is only one of the possible points of view. In the cosmological view, Maoris see nature as the ancestor of man, they see a deep relationship between man and nature, and this relationship is not about the subordination of the latter, but about the coexistence with equal rights. Man is, therefore, not the master of nature, but a part of $\mathrm{it}^{16}$. The government of New Zealand has accepted the Maori point of view and created a legal framework for this kind of view. This acceptance was not immediate though - it took over 100 years ${ }^{17}$.

The consequence of considering a river as a legal person is that it cannot be owned by anyone ${ }^{18}$. The recognition of the river's independence raised the question of who should act on its behalf ${ }^{19}$. An office - Te Pou Tupua - consisting of two people is appointed to represent the river - one of them is nominated by the Whanganui tribe and the other by the government of New Zealand ${ }^{20}$. They are obliged to act on behalf and for the sake of the entity they represent.

\section{NEW ZEALAND: TE UREWERA AND MOUNT TARANAKI}

Te Urewera forest area was recognized as a legal person on similar terms ${ }^{21}$. It is the largest national park on the north island of New Zealand. Section 8 of the Tūhoe Claims Settlement Act 2014 describes the history of the Tūhoe tribe's struggle for Te Urewera area with the government. One of the purposes of the act, in addition to providing compensation to the Tūhoe tribe for violating their rights

${ }^{15}$ More broadly, see D. Young, Whanganui tribes, https://teara.govt.nz/en/whanganui-tribes/ page-1 [access: 5.11.2019].

${ }^{16}$ More broadly, see C.J. Iorns Magallanes (op. cit.): "The adoption of the indigenious view of nature as a kin, rather than simply as a resource, refletcts the many calls for nature to be conceived of as more than property and as more than a slave to human needs and desires".

${ }^{17}$ E.C. Hsiao, Whanganui River Agreement - Indigenous Rights and Rights of Nature, "Environmental Policy and Law" 2012, Vol. 42(6), p. $371 \mathrm{ff}$.

${ }^{18}$ See ibidem, p. 374.

19 C.M. Kauffman, P.L. Martin, When Rivers Have Rights: Case Comparisons of New Zealand, Colombia, and India, International Studies Association Annual Conference, San Francisco, 4 April 2018, http://files.harmonywithnatureun.org/uploads/upload585.pdf [access: 5.11.2019].

${ }^{20}$ See points 18 i 20 of Te Awa Tupua (Whanganui River Claims Settlement) Act 2017. Point 18: "(1) The office of Te Pou Tupua is established. (2) The purpose of Te Pou Tupua is to be the human face of Te Awa Tupua and act in the name of Te Awa Tupua. (3) Te Pou Tupua has full capacity and all the powers reasonably necessary to achieve its purpose and perform and exercise its functions, powers, and duties in accordance with this Act". Point 20 of the Act concerns the appointment of Te Awa Tupua.

${ }^{21}$ More broadly, see C.J. Iorns Magallanes, op. cit., p. 8. 
(eventually NZD 170 million in damages was obtained), was obtaining the status of a legal person by Te Urewera 22 .

On July 31, 2008, the Crown signed the Terms of Negotiation with Te Kotahi $\bar{a}$ Tūhoe. The Crown and Tūhoe signed a high-level relationship statement (Nā Kōrero Ranatira ā Tūhoe me Te Karauna) on July 2, 201123. On March 22, 2013, Tühoe and the Crown initialed a Deed of Settlement, which was then ratified by the people of Tūhoe and signed on June 4, 2013. The agreement clearly stated that Te Urewera will have its own legislation and it will exist as a separate legal identity, being governed by Tūhoe and Crown nominees to act in the best interests of the $\operatorname{area}^{24}$. As of today, the agreement has not yet been implemented, so Te Urewera is not a legal person in the legal system of New Zealand.

A very interesting justification for the efforts of people living in and associated with this area, determining the significance of Te Urewera area for Maoris, is worth quoting:

Te Urewera is ancient and enduring, a fortress of nature, alive with history; its scenery is abundant with mystery, adventure, and remote beauty. Te Urewera is a place of spiritual value, with its own mana and mauri. Te Urewera has an identity in and of itself, inspiring people to commit to its care ${ }^{25}$.

Further negotiations are underway to give legal status to Mount Taranaki. Terms of negotiation were also signed in this matter ${ }^{26}$. Mount Taranaki is also of great importance in Maori culture. As stated in the Terms of Negotiation:

The maunga [mountains - J.B.] are pou [pillars - J.B.] that form a connection between the physical and the social elements of our lived experience. For Iwi of Taranaki, they have been ever present and remain personified ancestors, a site of shared history, a physical resource, and the citadel of a unique ecosystem. Wider Taranaki society continues to look upon these maunga as key reference points for the region, shaping an immediate sense of place and social association with mutual identity. Their presence pervades our scenery, projecting mystery, adventure and beauty, capturing our attention and our imagination in how humanity can be closely bound to a landscape ${ }^{27}$.

${ }^{22}$ See Tūhoe Claims Settlement Act 2014, www.legislation.govt.nz/act/public/2014/0050/latest/ DLM5481230.html [access: 5.11.2019].

${ }^{23}$ Deed of Settlement between The Crown and Tuhoe, 4 June 2013, Summary, www.govt.nz/ treaty-settlement-documents/ngai-tuhoe/ngai-tuhoe-deed-of-settlement-summary-4-jun-2013/background [access: 5.11.2019].

${ }^{24}$ Ibidem.

${ }^{25}$ Ibidem.

${ }^{26}$ Ngā Iwi o Taranaki and The Crown, Te Anga Pgtakerongo mo Nga Maunga o Taranaki, Pouakai me Kaitake, Record of understanding for Mount Taranaki, Pouakai and the Kaitake Ranges, www. govt.nz/dmsdocument/7265 Te-Anga-Putakerongo-Record-of-Understanding-20-December-2017. pdf [access: 5.11.2019].

${ }^{27}$ See point 1.7 of the above-mentioned Treaty. 


\section{INDIA: GANGES AND YAMUNA RIVERS}

At the same time as the Whanganui River was recognized as a legal person in New Zealand, on March 20, 2017, the Indian High Court of Uttarkhand recognized the Ganges river and its main tributary, Yamuna, as legal persons ${ }^{28}$. A few days later, the same court extended the concept of legal personality to the glaciers feeding both rivers ${ }^{29}$. The decision was caused by the fact that the rivers were ceasing to exist as a result of human activity, they were very polluted. It was supposed to be a way to improve their condition. Religious and cultural considerations also have been taken into account - the unique status of these rivers in the beliefs and culture of India ${ }^{30}$. As set out in the judgement, the rivers were considered "legal and living entities having the status of legal person with all corresponding rights, duties and obligations [...]". It concerned the Ganges river, its main tributary, the Yamuna, and "all their tributaries, streams, every natural water flowing with flow continuously or intermittently of these rivers [...]".

Already in July 2017, the Supreme Court of India declared ineffective the decision of the Uttarakhand state court establishing the legal personality of the two rivers. The Uttarakhand state government appealed to the Supreme Court arguing that such a solution is unlawful ${ }^{31}$. The case was pending in the Supreme Court and as of today (October 2019) the judgement has still not been issued ${ }^{32}$, which means that there is no binding decision on the legal personality of the Ganges and Yamuna.

The main motive behind the actions of the Indian court was to explicitly pay attention to the ecological disaster affecting the Ganges and Yamuna rivers. The chances of maintaining the sentence are, however, small, considering that the Ganges flows through five Indian states, and the judgement of only one of them went so far towards protecting the river ${ }^{33}$.

In the case of India, we are dealing not with the legislator, but with a court judgement trying to change the legal system. The chances of maintaining this judgement are small - specific legislative initiatives are needed for this type of change. Also, the Indian reality is not ready for a radical change of approach to the

${ }^{28}$ Judgement of the High Court of Uttarakhand at Naintal Writ Petition (PIL) of 5 December 2016, case No. 126 of 2014, Mohd Salim vs State of Uttarakhand \& others, www.casemine.com/ judgement/in/5b1a21874a932631a5a08d3f [access: 5.11.2019].

29 Judgement of the High Court of Uttarakhand of 30 March 2017, Lalit Miglani vs State of Uttarakhand and others, https://indiankanoon.org/doc/92201770 [access: 5.11.2019].

${ }^{30}$ E.L. O'Donnell, At the Intersection of the Sacred and the Legal: Rights for Nature in Uttarakhand, India, "Journal of Environmental Law" 2018, Vol. 30(1), DOI: https://doi.org/10.1093/jel/eqx026.

31 India's Ganges and Yamuna rivers are 'not living entities', www.bbc.com/news/world-asiaindia-40537701 [access: 5.11.2019]

${ }^{32}$ K.D. Alley, T. Mehta, The experiment with rights of nature in India, [in:] Sustainability and the Rights of Nature in Practise, eds. C. La Follette, C. Maser, Boca Raton 2019.

${ }^{33}$ Ibidem. 
protection of both rivers. However, the justification of the judgement, written with great passion, knowledge of culture, literature, beliefs, indicates that changing the approach to protecting the Ganges and Yamuna is a necessity, that these rivers are becoming biologically dead and this is the last moment to save them.

\section{COLOMBIA: RIO ATRATO AND THE AMAZON ECOSYSTEM}

In November 2016 Colombia's Constitutional Court declared that the Atrato River basin possesses rights to "protection, conservation, maintenance, and restoration" ${ }^{34}$. The reason for such an unusual judgement was the significant degradation of the river - as stated in the justification: "[...] the significant degradation of the Atrato River basin from mining, impacting nature and indigenous peoples" ${ }^{\prime 35}$. Illegal mining activities near the Atrato River have caused significant pollution to the river and the residential areas surrounding it. Colombia's Constitutional Court described this as a deep humanitarian and environmental crisis. The judgement recognizes the right of the Atrato River "to be protected, preserved and restored". To guarantee the interests of the river, two representatives of the river were established - one member of the community living in the area and one member of the government ${ }^{36}$.

A fragment of the justification of the judgement of Colombia's Constitutional Court is worth quoting:

$[\ldots]$ it is the human populations that are interdependent of the natural world - and not the opposite - and that they must assume the consequences of their actions and omissions with nature. It is a question of understanding this new socio-political reality with the aim of achieving a respectful transformation with the natural world and its environment, as has happened before with civil and political rights $[\ldots]$. Now is the time to begin taking the first steps to effectively protect the planet and its resources before it is too late $[\ldots]^{37}$.

In 2018 the Supreme Court of Colombia recognized the Amazon ecosystem, including its river and forest territory, as a legal subject ${ }^{38}$ and forced the govern-

${ }^{34}$ Press Release: Colombia Constitutional Court Finds Atrato River Possesses Rights, May 4, 2017, https://celdf.org/2017/05/press-release-colombia-constitutional-court-finds-atrato-river-possesses-rights [access: 5.11.2019].

35 Ibidem.

36 See L. Cano Pecharroman, Rights of Nature: Rivers That Can Stand in Court, "Resources" 2018, Vol. 7(13), DOI: https://doi.org/10.3390/resources7010013.

37 Press Release: Colombia Constitutional Court Finds ...; the operative part of the judgement of the Constitutional Court of the Republic of Colombia of 5 April 2018, http://cr00.epimg.net/descargables/2017/05/02/14037e 7b5712106cd88b687525dfeb4b.pdf [access: 5.11.2019].

${ }_{38}$ The operative part of the judgement of the Supreme Court of Justice of the Republic of Colombia of April 5 2018, http://legal.legis.com.co/document/Index?obra=jurcol\&document=jurcol_c947ae53aeb447bd91e8e9a315311ac5 [access: 5.11.2019]. 
ment of Colombia to take actions directed at controlling deforestation and thus the related climate and water cycle changes in the Amazon region. Deforestation of the Colombian Amazon has increased by $44 \%$ in the last 3 years. A group of children and adolescents aged from 7 to 25 brought the Amazon case to court, in which they claimed that the government's inaction violated their constitutionally protected human rights to life, water, and healthy environment ${ }^{39}$.

The actions taken in Colombia are a manifestation of the attempt of the courts to press the government to take action towards environmental protection. However, the effectiveness of this type of action will depend on the legislative and executive powers. And in this respect, current economic interests still often outweigh the protection of our future.

\section{CONCLUSIONS}

Recognition of independent rights of nature, their acceptance and incorporation into the legal system requires not only changes in the law, but also the transformation of the paradigm of the legal system, putting human in the absolute centre ${ }^{40}$. Certainly, one reason for implementing the concept of the river as a legal person was to translate the beliefs and customs of peoples with values other than those of the Western civilization into the concepts of the Western legal system ${ }^{41}$. However, the main motive of attempts to introduce this type of construction is the failure of the current environmental protection system and the search for more effective instruments, while relying on a different worldview. The subjectivity of nature is recognized in many religious systems, the approach to nature as an equal partner having its own rights is not alien to many cultures, but it is visible not in the legal systems but in their customs and beliefs. The legal system known to the western world, which largely dominated the world, recognizes the forest, mountains, rivers as objects of ownership and does not recognize them as subjects of law.

Certainly, the fears that due to the change of approach man will lose his central place in the system are not justified, because the legal system is a human construction. Changing the view of nature in the context of subjectivity will allow one to see more problems, protect better. The need to protect nature is now undoubtedly recognized by all societies, regardless of cultural orientation.

39 See J. Torres, E. Macpherson, The Tour to Save the World: Colombia Wins the Yellow Jersey for the Rights of Nature, 23 August 2019, www.iconnectblog.com/2019/08/the-tour-to-save-theworld-colombia-wins-the-yellow-jersey-for-the-rights-of-nature [access: 5.11.2019].

${ }^{40}$ See L. Cano Pecharroman, op. cit., p. 1.

${ }^{41}$ See J. Jaśtal, Czy rzeka może być osoba prawna, ,Filozofuj” 2018, nr 3, pp. 41-42. 
Actions taken in India and Colombia have a different meaning and different background than in New Zealand. In New Zealand, we deal with legal solutions developed over many years that are rooted in Maori beliefs and culture. Specific changes in the law are to guarantee the implementation of the reached agreements. In the cases of India or Colombia, however, we are dealing with its own initiative of the judiciary, with judgements that are intended to be an alarm, a strong voice advocating for the laws of nature. However, the chances of a broader recognition of this approach depend on specific changes in the law and on the actions of the legislator.

In Europe, there are currently no attempts to change the law towards recognizing elements of nature as legal persons, but the discussion on this subject can certainly bring a lot to consider about the condition of the modern world, the objectification of nature, and the effects of such behaviour. Certainly, we are on the threshold of an ecological disaster on a scale unprecedented in the history of the world and current legal solutions are not sufficient to prevent such a disaster. In the current journalism discourse, also in Poland, there are postulates regarding using the legal constructions present in New Zealand as a way to combat the industry that destroys nature ${ }^{42}$. However, for now, the chances of introducing such solutions should be considered as negligible.

\section{REFERENCES}

\section{Literature}

Alley K.D., Mehta T., The experiment with rights of nature in India, [in:] Sustainability and the Rights of Nature in Practise, eds. C. La Follette, C. Maser, Boca Raton 2019.

Babcock H.M., A Brook with Legal Rights: The Rights of Nature in Court, "Ecology Law Quarterly" 2016, Vol. 43(1).

Berros M.V., Defending Rivers: Vicamaba in the South of Ecuador, "Perspectives Issue" 2017, No. 6. Cano Pecharroman L., Rights of Nature: Rivers That Can Stand in Court, "Resources" 2018, Vol. 7(13), DOI: https://doi.org/10.3390/resources7010013.

Clark C., Emmanouil N., Page J., Pelizzon A., Can You Hear the Rivers Sing? Legal Personhood, Ontology, and the Nitty, Gritty of Governance, "Ecology Law Quarterly" 2018, Vol. 45.

Colwell R., Carr-Wilson S., Sandborn C., Legal Personality of Natural Features: Recent International Developments and Applicability in Canada, 2017, www.elc.uvic.ca/wordpress/wp-content/uploads/2018/05/2017-02-03-LegalPersonalityNatural-Features_web-version.pdf [access: 5.11.2019].

${ }^{42}$ See R. Rient, Rzeka, którq zabijamy, „Przekrój” 2019, https://przekroj.pl/spoleczenstwo/ rzeka-ktora-zabijamy-robert-rien [access: 5.11.2019] and contained here fully justified sentences regarding the Noteć river and the ecological catastrophe that affected the river: "To save rivers threatened by the operation of the mines and the climate crisis, first you must try to understand the river and see in it a living organism that directly supports our lives and thousands species. Therefore, stop treating rivers as a resource, commodity or sewage". 
De Vries-Stotijn A., Van Ham I., Bastmeijer K., Protection through property: from private to river-held rights, "Water International" 2019, Vol. 44(6-7),

DOI: https://doi.org/10.1080/02508060.2019.1641882.

Frąckowiak J., Osoby prawne, [in:] System Prawa Prywatnego, t. 1: Prawo cywilne-część ogólna, red. M. Safjan, Warszawa 2007.

Hsiao E.C., Whanganui River Agreement - Indigenous Rights and Rights of Nature, "Environmental Policy and Law" 2012, Vol. 42(6).

India's Ganges and Yamuna rivers are 'not living entities', www.bbc.com/news/world-asia-india-40537701 [access: 5.11.2019].

Iorns Magallanes C.J., Nature as an Ancestor: Two Examples of Legal Personality for Nature in New Zealand, „VertigO - la revue electronique en sciences de l'environnement” 2015, serie 22, DOI: https://doi.org/10.4000/vertigo.16199.

Jaśtal J., Czy rzeka może być osoba prawna, „Filozofuj” 2018, nr 3.

Joseph R., Rakena M., Kuini Jones M.T., Sterling R., Rakena C., The Treaty, Tikanga Māori, Ecosystem-Based Management, Mainstream Law and Power Sharing for Environmental Integrity in Aotearoa New Zealand - Possible Ways Forward, Waikato 2019, https://sustainableseaschallenge.co.nz/sites/default/files/2019-02/MAIN\%20TuhonohonoSSeas\%20Final\%20Report\%20 Nov\%202019.pdf [access: 5.11.2019].

Kauffman C.M., Martin P.L., When Rivers Have Rights: Case Comparisons of New Zealand, Colombia, and India, International Studies Association Annual Conference, San Francisco, 4 April 2018, http://files.harmonywithnatureun.org/uploads/upload585.pdf [access: 5.11.2019].

O'Donnell E.L., At the Intersection of the Sacred and the Legal: Rights for Nature in Uttarakhand, India, "Journal of Environmental Law" 2018, Vol. 30(1), DOI: https://doi.org/10.1093/jel/eqx026.

O’Donnell E.L., Maloney M., Parker C., New developments in the legal status of rivers, 11 August 2017, https://law.unimelb.edu.au/_data/assets/pdf_file/0007/2516479/Legal-rights-for-riversWorkshop-Report.pdf [access: 5.11.2019].

O'Donnell E.L., Talbot-Jones J., Creating legal rights for rivers: Lessons from Australia, New Zealand, and India, "Ecology and Society" 2018, Vol. 23(1),

DOI: https://doi.org/10.5751/ES-09854-230107.

Press Release: Colombia Constitutional Court Finds Atrato River Possesses Rights, May 4, 2017, https://celdf.org/2017/05/press-release-colombia-constitutional-court-finds-atrato-river-possesses-rights [access: 5.11.2019].

Rient R., Rzeka, którą zabijamy, „Przekrój” 2019, https://przekroj.pl/spoleczenstwo/rzeka-ktora-zabijamy-robert-rien [access: 5.11.2019].

Stone Ch.D., Should Trees Have Standing? Law, Morality and the Environment, Oxford 2010.

Stone Ch.D., Should Trees Have Standing? - Towards Legal Rights for Natural Objects, "Southern California Law Review" 1972, Vol. 45.

Summary of the historical background to the Whanganui River claims of Whanganui Iwi, www.govt. $\mathrm{nz} /$ treaty-settlement-documents/whanganui-iwi/whanganui-iwi-whanganui-river-deed-of-settlement-summary-5-aug-2014/background [access: 5.11.2019].

Torres J., Macpherson E., The Tour to Save the World: Colombia Wins the Yellow Jersey for the Rights of Nature, 23 August 2019, www.iconnectblog.com/2019/08/the-tour-to-save-the-world-colombia-wins-the-yellow-jersey-for-the-rights-of-nature [access: 5.11.2019].

Young D., Whanganui tribes, https://teara.govt.nz/en/whanganui-tribes/page-1 [access: 5.11.2019]. 


\section{Legal acts}

Deed of Settlement between The Crown and Tuhoe, 4 June 2013, Summary, www.govt.nz/treaty-settlement-documents/ngai-tuhoe/ngai-tuhoe-deed-of-settlement-summary-4-jun-2013/background [access: 5.11.2019].

Ngā Iwi o Taranaki and The Crown, Te Anga Pgtakerongo mo Nga Maunga o Taranaki, Pouakai me Kaitake, Record of understanding for Mount Taranaki, Pouakai and the Kaitake Ranges, www.govt.nz/dmsdocument/7265 Te-Anga-Putakerongo-Record-of-Understanding-20-December-2017.pdf [access: 5.11.2019].

Te Awa Tupua (Whanganui River Claims Settlement) Act 2017, www.legislation.govt.nz/act/public/2017/0007/latest/whole.html\#DLM6831461 [access: 5.11.2019]

Tūhoe Claims Settlement Act 2014, www.legislation.govt.nz/act/public/2014/0050/latest/ DLM5481230.html [access: 5.11.2019].

Whanganui Iwi and the Crown, "Record of understanding in relation to Whanganui River settlement", October 13, 2011, www.ngatangatatiaki.co.nz/assets/Uploads/Important-Documents/DocumentLibrary_WhanganuiRiverROU.pdf [access: 5.11.2019].

\section{Case law}

Judgement of the Constitutional Court of the Republic of Colombia of 5 April 2018, http://cr00.epimg. net/descargables/2017/05/02/14037e7b5712106cd88b687525dfeb4b.pdf [access: 5.11.2019].

Judgement of the High Court of Uttarakhand at Naintal Writ Petition (PIL) of 5 December 2016, case No. 126 of 2014, Mohd Salim vs State of Uttarakhand \& others, www.casemine.com/judgement/ in/5b1a21874a932631a5a08d3f [access: 5.11.2019].

Judgement of the High Court of Uttarakhand of 30 March 2017, Lalit Miglani vs State of Uttarakhand and others, https://indiankanoon.org/doc/92201770 [access: 5.11.2019].

Judgement of the Supreme Court of Justice of the Republic of Colombia of April 5 2018, http:// legal.legis.com.co/document/Index?obra=jurcol\&document=jurcol_c947ae53aeb447bd91e8e9a315311ac5 [access: 5.11.2019].

\section{STRESZCZENIE}

Koncepcje uznania elementów natury za mające osobowość prawną pojawiają się od wielu lat jako propozycje nowego podejścia do ekologii. Ostatnie lata przyniosły w tym zakresie konkretne rozwiązania. W różnych miejscach na świecie spotkać można próby uznania rzek (ale nie tylko) za odrębne podmioty prawa. Nie jest to powszechna tendencja, tylko kilka takich przypadków można zidentyfikować w obowiązujących ustawodawstwach. Artykuł poświęcono analizie najbardziej znanych przykładów tego rodzaju działań. W systemie prawnym Nowej Zelandii uznano w 2017 r. rzekę Whanganui za osobę prawną. Toczą się rozmowy na temat dalszych tego rodzaju rozwiązań. Podstawowym motywem takich rozwiązań, oprócz względów ochrony środowiska, są względy kulturowe - związane z systemem wierzeń i wartości Maorysów. W systemach prawnych Indii i Kolumbii sądy podjęły próby uznania rzek (Gangesu i Yamuny w Indiach, rzeki Atrata oraz całego ekosystemu Amazonki) za osoby prawne. Motywy tego rodzaju działań były przede wszystkim ekologiczne ochrona bezcennych części przyrody przed zniszczeniem.

Słowa kluczowe: ochrona środowiska; osobowość prawna; rzeka jako osoba prawna; ekologia 